\title{
Analysis of Export Value, Capita Expenditure, and Inflation Against Economic Growth
}

\author{
Zulfahmi Syahputra Nasution ${ }^{1}$, Hasan Basri Tarmizi ${ }^{2}$, Muhammad Syafii ${ }^{3}$ \\ ${ }^{1,2,3,4}$ Faculty of Economics and Business, Universitas Sumatera Utara, Indonesia \\ syahputrazulfahmi@gmail.com
}

Abstract

Economic growth is an indicator that is often used for economic conditions in developing countries like Indonesia. Growing the economy of a region can be done by increasing economic activities in the area. This research was conducted with the aim of seeing and showing the effect of export value, inflation and per capita expenditure on economic growth in North Sumatra. The research was conducted using quantitative methods using datafrom 1990 to 1999 based on the variables used in the variables in this study. Export value and per capita expenditure have an effect on Economic Growth in North Sumatra Province. The value of the results of the comparative test or $t$ test conducted shows that the variable export value has a value of 2.826 and 2.323 so that there is an influence that affects economic growth. Meanwhile, inflation does not have a significant effect on Economic Growth in North Sumatra Province. Based on the t-test, the output of the inflation variable gets a value of $-8,431$, so it can be stated that economic growth in North Sumatra cannot occur positively on inflationary activity in North Sumatra.
Keywords economic growth; export value; inflation and capita expenditure

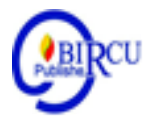

\section{Introduction}

Economic growth is an indicator that is often used to determine economic conditions, especially economies in developing countries such as Indonesia. Economic growth can be seen from the quality and quantity of economic activity in the area (Hidayat: 2017; Jones, J., \& Wren, C.: 2016). Besides, this is influenced by how the decentralization policy and per capita income in a region. Low economic growth can result in conditions of poor people, this causes a person to spend his income only for food or food needs and will ignore other needs such as education and health (Dao and Edenhofer, 2018: 255). Growing the economy of a region can be done by increasing economic activities in the area.

Economic activities are no longer limited to trade and financial aspects but extend to production and marketing aspects, even human resources as a consequence of all of this. Economies between countries are increasingly closely related, economic events in a country quickly and easily spread to other countries. In a situation like now, business and economic advantages are no longer based on a comparative advantage strategy (comparative advantage) but a competitive advantage strategy (Austin and Pisano: 2017). Globalization has fundamentally changed the structure of the world economy. The interdependence (interdependence) of the country's economy is getting tighter, this closeness of interdependence takes place not only between developed countries but also between developing countries and developed countries. 
The role of foreign trade in economic development is considered prominent (North: 2016). Classical and neoclassical economists reveal how important international trade is in the development of a country, to the point that it is considered an engine of growth. The opposite view assumes that historically foreign trade has caused international disparities; rich countries become rich at the expense of poor countries. Therefore it is said that although underdeveloped countries are forced to sacrifice the benefits arising from international specialization (Jackson: 2016), by implementing import substitution policies and planned industrialization and expanding output for domestic consumption, a higher level of development can be achieved.

Economic growth in Indonesia from 2016 to 2018 has a stable increase of 0.04 to 0.1. Economic growth is influenced by global economic factors that continue to grow despite slowing down and rising commodity prices. The relationship between inflation and economic growth is one of the debatable issue and the most important macroeconomic discussions among macro economists, policy-makers and monetary authorities in all countries (Wollie, G., 2018). The economic development of a region will cause changes in the role of each sector resulting in changes in the economic structure of the area (Irwansyah in Lubis, 2020). From the domestic side, this performance was influenced by increased investment, continued growth in exports, and stable private consumption. Schumpeter's theory (Aghion and Festre: 2017; Chakravarty: 2017) also touches on the international trade process carried out by entrepreneurs who play a role in realizing economic growth. International trade itself is divided into two types of trading activities, namely Exports and Imports (Ngo \& Janssen: 2016). In the data on the Economic Development of Indonesia and the World in Quarter I 2018, it is stated that the total value of Indonesia's exports in the first quarter of 2018 was USD 44,265.8 million, an increase of 8.78 per cent when compared to the same period in 2017.

Exports of goods and services grew by $6.2 \%$, slowing down from the first quarter of 2017 and the previous quarter which amounted to $8.4 \%$ and $8.5 \%$, respectively. This condition is mainly influenced by commodity prices that are still growing and the economies of major trading partner countries that are growing quite strongly. The value of non-oil and gas exports by sector up to the first quarter of 2018 was supported by the industrial sector of $31,999.3$ million with a proportion of 72.3 per cent of the total value of Indonesia's total exports. According to data from the Central Bureau of Statistics, in 2011 the highest export activity was in North Sumatra Province in vegetable and animal oil export activities.

Per capita expenditures that can be viewed from the expenditure for financing the Regional Expenditure Development Budget are in the form of routine and development expenditures. The increase in government spending is expected to have the ability to create increased development facilities and infrastructure and in the end will encourage aggregate demand to also increase (Darmayanti: 2019), so that it can stimulate regional production activities, which in turn can increase the rate of economic growth. Community income is the main factor affecting per capita expenditure (Permana, A., Rustamunadi, R., \& Sunardi, D.: 2019). The relationship between the two is positive, that is, when income increases, the level of expenditure for public consumption increases. Inflation as a condition which tends to increase prices generally and continuously.

The talk of inflation became very popular in Indonesia when the inflation rate was so high that it reached 650 per cent in the mid-1960s. The high inflation with its various negative implications has caused the government to pay special attention to the inflation rate. With macroeconomic policies aimed at suppressing the inflation rate, entering the 
1980s the inflation rate had begun to be suppressed. Even in the following years, the inflation rate in Indonesia has never experienced double-digit inflation again. Inflation in Indonesia once reached its highest point, namely in the mid-1960s where there was hyperinflation that hit the national economy with an inflation rate of up to 650 per cent (Aprillia, H.: 2011). This was mainly due to the deficit in the government budget which later financed by Bank Indonesia in the form of money printing. The inflation rate in North Sumatra during 1998-2010 shows fluctuation which varies from time to time.

\section{Research Methods}

This research is a quantitative descriptive. Using secondary data as data in this study in the form of quantitative data. The data in this study are secondary data obtained from the Central Statistics Agency of North Sumatra Province which is related to the variables in this study. The variables used are export value, per capita expenditure and inflation on economic growth in North Sumatra Province. The data used in this study use annual data in the period 1990-2019, which then the data will be processed as multiple linear regression data, so this research is the result of using data for the annual period. Regression analysis is a study of the dependence of the dependent variable with one or more independent variables. It aims to estimate and predict the average value of the dependent variable based on the known value of the independent variable.

\section{Results and Discussion}

The maximum value on the variable export value in the data from 1990 to 2019 in North Sumatra Province is 11883 USD or IDR $166,362,000$ and the minimum value is 1542 USD or $21,588,000$ IDR. It can be seen that the export activities of North Sumatra Province are experiencing good dynamics so that there is a significant difference from the maximum and minimum export values. The maximum value of the inflation variable is $83.56 \%$ and the minimum value is $1.23 \%$. If the inflation rate is getting smaller it can be interpreted that the economic growth is getting better. the average value of export value is 7050.13 USD or IDR 98,830,132 from data from 1990 to 2019. Then in the inflation rate, the average value for this variable is $9.58 \%$, expenditure per capita on food needs is $54.8 \%$ and for non-food items is $43.20 \%$ and the economic growth in Sumatra Province the average value is $5.54 \%$.

The maximum value of the inflation variable is $83.56 \%$ and the minimum value is $1.23 \%$. If the inflation rate is getting smaller it can be interpreted that the economic growth is getting better. The per capita expenditure data for food needs, has a maximum value of $86.67 \%$ and a minimum value of $12.24 \%$, while for non-food needs, the maximum value is $87.76 \%$ and the minimum value is $13.33 \%$. The minimum and maximum values on per capita expenditure indicate that economic activity in North Sumatra Province is very dynamic by seeing the difference in seginfikan from the stated minimum and maximum.

In the economic growth of North Sumatra Province from 1990-2019 data, the maximum value was $9.48 \%$ and the minimum value was $-10.90 \%$. Based on this, it can be seen that there has been a significant change in the value of growth in North Sumatra Province from 1990 to 2019 which is supported by various economic activities such as export activities, inflation, and per capita expenditure. 
Table 1. One-Sample Kolmogorov-Smirnov Test

\begin{tabular}{|ll|r|}
\hline & & \multicolumn{2}{|c|}{ Unstandardized Residual } \\
\hline N & Mean & 30 \\
Normal Parameters & a, & Std. \\
& Deviation & 1.63066187 \\
& Absolute & .081 \\
Most Extreme & Positive & .081 \\
Differences & Negative & -.081 \\
Kolmogorov-Smirnov Z Z & .445 \\
Asymp. Sig. (2-tailed) & & .989 \\
\hline
\end{tabular}

a. Test distribution is Normal.

b. Calculated from data.

The results of the normality test using the Kolmogorov Smirnov test through SPSS. Asymp Value. Sig (2-tailed) for each variable above the value of 0.05 . The data on each independent variable used has a normal value. Based on the results on. All variable data are normally distributed, so it can be interpreted that all data on each variable has a normal value of 0.989 , this can be said that all data are normal. So that economic growth in North Sumatra Province has a normal value in each value of growth, if it is related to the variables used in the tests that have been carried out.

Table 2. Coefficients ${ }^{\mathrm{a}}$

\begin{tabular}{|c|c|c|c|c|c|}
\hline \multirow[t]{2}{*}{ Model } & \multicolumn{2}{|c|}{$\begin{array}{l}\text { Unstandardized } \\
\text { Coefficients }\end{array}$} & \multirow{2}{*}{$\begin{array}{c}\text { Standardized } \\
\text { Coefficients } \\
\text { Beta }\end{array}$} & \multirow[t]{2}{*}{$\mathrm{t}$} & \multirow[t]{2}{*}{ Sig. } \\
\hline & B & Std. Error & & & \\
\hline (Constant) & 1.893 & 4.065 & & 2.188 & .038 \\
\hline EXPORTVALUE & 2.39 & .000 & -.302 & 2.826 & .009 \\
\hline INFLATION & -.213 & .025 & -.888 & -8.431 & .082 \\
\hline $\begin{array}{l}\text { CAPITAFOODEX } \\
\text { PENDITURE }\end{array}$ & .204 & .044 & .081 & 2.323 & .029 \\
\hline $\begin{array}{l}\text { CAPITANONFOO } \\
\text { DEXPENDITURE }\end{array}$ & .102 & .047 & .022 & 2.090 & .014 \\
\hline
\end{tabular}

a. Dependent Variable: Economicgrowth

Based on the test results of multiple linear regression analysis, the regression equation can be stated as follows:

$$
Y=1.89+2,39 X_{1}-0,21 X_{2}+0,20 X_{3}
$$

A constant value of 1.89 indicates that if the value of exports, inflation and expenditure per capita is constant, then the economic growth rate is $1.89 \%$. The coefficient value of the export value is 2.39 , indicating that if the other independent variables are fixed and the level of export value increases by one per cent, the value of economic growth will increase by $2.39 \%$. The coefficient is positive, meaning that the value of exports is positively related to economic growth, so that if the value of exports increases, economic 
growth will increase, and vice versa. The inflation coefficient value of -0.21 indicates that if other independent variables remain and the inflation rate rises by one per cent, the value of economic growth will decrease by $0.21 \%$. The coefficient is positive, meaning that inflation is positively related to economic growth so that if the value of inflation decreases, economic growth will increase, and vice versa. The coefficient value of per capita expenditure is 0.20 , indicating that if other independent variables are fixed and the level of per capita expenditure increases by one per cent, the value of economic growth will increase by $0.20 \%$ and for non-food items by 0.10 , which means that it has a valuable effect of $0 ., 10 \%$ in economic growth. The coefficient is positive, meaning that the value of per capita expenditure is positively related to economic growth so that if per capita expenditure increases, economic growth will increase, and vice versa.

The results of statistical tests show that the variables of export value and expenditure per capita have a positive and significant effect on. This means that if population growth increases, the poverty rate will also increase. However, the inflation variable does not have a significant effect, so that if the rate of inflation decreases, economic growth will increase, and vice versa.

The inflation variable becomes a variable that is not very significant in economic growth in North Sumatra, using data from 1990 to 2019. There is an extreme value in inflationary activity in North Sumatra Province, which is located in 1998, which is valued at $83.56 \%$ which results in a value Economic growth in that year was also in the position of -10.9 , this was caused by the turmoil of the monetary crisis from 1997 to 1998.

\section{Conclusion}

Export Value has an effect on Economic Growth in North Sumatra Province. The value of the results of the comparative test or t-test conducted shows that the export value variable has a value of 2.826 which when compared with the t-table value of 2.05954 , the $\mathrm{t}$-count is still greater, so that there is a significant effect on economic growth.

Per Capita Expenditure affects Economic Growth in North Sumatra Province. tcount of 2.323 for food and 2.090 for non-food, which when compared with the t-table is 2.05954, it results in an influence between the variable per capita expenditure and economic growth in North Sumatra Province with data from 1990 to 2019.

Export Value and Per Capita expenditure are variables that have a significant effect on Economic Growth in North Sumatra Province, using data from 1990 to 2019. However, the inflation variable does not have the same meaning as the variables of export value and per capita expenditure.

\section{References}

Aghion, P., \& Festré, A. (2017). Schumpeterian growth theory, Schumpeter, and growth policy design. Journal of Evolutionary Economics, 27(1), 25-42.

Aprillia, H. (2011). Analisis Inflasi di Sumatera Utara: Suatu Model Error Correction (ECM). Quantitative Economics Journal, 1(2).

Austin, R. D., \& Pisano, G. P. (2017). Neurodiversity as a competitive advantage. Harvard Business Review, 95(3), 96-103.

Chakravarty, S. (2017). Alternative approaches to a theory of economic growth: Marx, Marshall and Schumpeter. 
Dao, N. T., \& Edenhofer, O. (2018). On the fiscal strategies of escaping povertyenvironment traps towards sustainable growth. Journal of macroeconomics, 55, 253273 .

Hidayat, W. (2017). Perencanaan Pembangunan Daerah: Pendekatan Pertumbuhan Ekonomi, Disparitas Pendapatan dan Kemiskinan. UMMPress.

Jackson, T. (2016). Prosperity without growth: foundations for the economy of tomorrow. Taylor \& Francis.

Jones, J., \& Wren, C. (2016). Foreign direct investment and the regional economy. Routledge.

Lubis, N.P.S., Nugrahadi, E.W., and Yuusuf, M. (2020). Analysis of Superior Commodities in Agricultural Sector in Some Districts of North Sumatera Province. Budapest International Research and Critics Institute-Journal (BIRCI-Journal) Vol 3 (2): 1054-1066.

Ngo, V. D., Janssen, F., Leonidou, L. C., \& Christodoulides, P. (2016). Domestic institutional attributes as drivers of export performance in an emerging and transition economy. Journal of Business Research, 69(8), 2911-2922

North, D. C. (2016). Institutions and economic theory. The american economist, 61(1), 7276.

Permana, A., Rustamunadi, R., \& Sunardi, D. (2019). Pengaruh Pengeluaran Per Kapita Terhadap Indeks Pembangunan Manusia Di Provinsi Banten Periode 2012-2016. Tazkiya, 20(01), 01-21.

Wollie, G. (2018). The Relationship between Inflation and Economic Growth in Ethiopia. Budapest International Research and Critics Institute-Journal (BIRCI-Journal) Vol I (3): 264-271. 